\title{
PENGARUH PENERAPAN STRATEGI PEMBELAJARAN AKTIF TIPE AKTIVE KNOWLEDGE SHARING DISERTAI KUIS TERHADAP PEMAHAMAN KONSEP MATEMATIS SISWA KELAS X SMA DR. H. ABDULLAH AHMAD PGAI PADANG
}

\author{
Rahmania Nasir, Rahmi, Rina Febriana \\ Program StudiPendidikanMatematika STKIP PGRI Sumatera Barat \\ rahmanianasir95@gmail.com
}

Submitted: 23-05-2017, Reviewed: 03-06-2017, Accepted: 25-08-2017

\begin{abstract}
The background of this research is understanding student's mathematical concept in teaching learning process still low and the student less want to divisible the knowledge in learn. The purpose of this research is to know how is the development of understanding student's mathematical concept and what is the understanding of student's mathematical concept with apply Active Knowledge Sharing type along with quiz better than understanding student's mathematical concept with apply convensional learning in class X SMA PGAI Padang. The kind of this research is experimental research with random plan toward subject. The population of this research is the students of X class SMA PGAI Padang. The technique of take the sample is random. Selected the X.2 class as experimental class and X.1 class as control class. The instrument that used in this research are quiz and the final test. According to quiz analysis found that understanding students mathematical concept after gived the treatment low experienced and increased on every meeting. Hyphotheses testing used t test one side resulted. $t_{\text {count }}=1,746$ and $t_{\text {table }}=1.697$ on $\alpha=0,05$. So that $t_{\text {count }}>t_{\text {table }}$. So, acceptance hypotheses was understanding students mathematical concept with apply active knowledge sharing type along with quiz better than understanding students mathematical concept with apply conventional learning in class X SMA PGAI Padang
\end{abstract}

Key word: quiz, Active Knowledge Sharing, understanding mathematical concept

\begin{abstract}
Abstrak. Penelitian ini dilatarbelakangi oleh pemahaman konsep matematis siswa dalam proses pembelajaran masih rendah dan siswa kurang mau berbagi pengetahuan dalam belajar. Penelitian ini bertujuan untuk mengetahui bagaimana perkembangan pemahaman konsep matematis siswa dan untuk mengetahui apakah pemahaman konsep matematis siswa dengan menerapkan model pembelajaran aktif tipe Active Knowledge Sharing disertai kuis lebih baik daripada pemahaman konsep matematis siswa dengan menerapkan pembelajaran konvensional di kelas X SMA PGAI Padang. Jenis penelitian adalah eksperimen dengan rancangan penelitian random terhadap subjek. Populasi penelitian adalah siswa kelas X SMA PGAI Padang. Teknik pengambilan sampel dilakukan secara acak. Terpilih kelas X.2 sebagai kelas eksperimen dan kelas X.1sebagai kelas kontrol. Instrumen yang digunakan adalah kuis dan tes akhir.Berdasarkananalisis kuis diketahui bahwa pemahaman konsep matematis siswa setelah diberi perlakuan mengalami penurunan dan peningkatan pada setiap pertemuan. Pengujian hipotesis mengggunakan uji-t satu pihak diperoleh $t_{\text {hitung }}=1,746$ dan $t_{\text {tabel }}=1,697$ pada $\alpha=0,05$, dengan demikian $t_{\text {hitung }}>t_{\text {tabel }}$ sehingga hipotesis diterima yaitu pemahaman konsep matematis siswa dengan menerapkan strategi pembelajaran aktif tipe Active Knowldge Sharing disertai kuis lebih baik dari pada pemahaman konsep matematis siswa yang menerapkan pembelajaran konvensional di kelasX SMA PGAI Padang.
\end{abstract}

Kata kunci: Kuis, Active Knowledge Sharing , pemahaman konsep matematis

\section{PENDAHULUAN}


Matematika merupakan cabang ilmu pengetahuan yang mempunyai peranan penting dalam dunia pendidikan. Mengingat peranan matematika yang begitu penting,diharapkan siswa dapat memahami pembelajaran matematika sesuai dengan tujuan pembelajaran matematika yang hendakdicapai.

Menurut Nikson dalam Mulyardi (2002:3) Pembelajaran matematika adalah upaya membantu siswa untuk mengontruksi konsep-konsep atau prinsip-prinsip matematika dengan kemampuannya sendiri melalui proses internalisasi sehingga konsep atau prinsip itu terbangun kembali. Transformasi informasi yang diperoleh menjadi konsep atau prinsip baru. Transformasi informasi tersebut dapat mudah terjadi bila terjadi pemahaman karena terbentuknya semata dalam benak siswa.Pembelajaran matematika akan selalu berhubungan dengan pemahaman dan penalaran. Pemahaman konsep matematika yang baik sangat penting, karena untuk memahami konsep yang baru diperlukan prasyarat pemahaman konsep sebelumnya.Semakin tinggi pemahaman konsep, maka semakin tinggi pula tingkat keberhasilan siswa dalam mencapai tujuan pembelajaran. Siswa yang memiliki pemahaman konsep yang baik mampu menyelesaikan soal-soal dengan baik.

Kenyataannya pembelajaran matematika selama ini belum berhasi lmeningkatkan pemahaman siswa terhadap konsep-konsep matematis.Pemahaman konsep siswa yang rendah juga berpengaruh terhadap hasil belajar siswa.Guru sangat berperan penting dalam mengatasi permasalahan diatas. Guru dituntut kreatif dalam memilih metode mengajar sehingga dapat memudahkan siswa mengingat materi, mengembangkan pola pikir dan melibatkan siswa aktif, kreatif dan termotivasi dalam belajar.

Berdasarkan hasil observasi pada tanggal 3-5 September 2016pada kelas X PGAI Padang, terlihat bahwa siswa kurang aktif dalam proses pembelajaran, siswa kebanyakan diam dan tidak mau bertanya kepada guru tentang materi yang belum dipahami. Pada saat diberikan latihan banyak siswa yang berpindah-pindah tempat duduk mendekati siswa yang berkemampuan tinggi, siswa hanya menyalin tugas teman yang berkemampuan tinggi tanpa tahu konsep yang digunakan. Siswa kurang mau berbagi pengetahuan, sehingga siswa tidak paham dengan konsep yang dipelajari.

Salah satualternatif yang mampu mengatasi berbagai masalah yang telah ditemukan adalah dengan menerapkan strategi pembelajaran aktif tipe Active Knowledge Sharing. Zaini (2008:22) menyatakan bahwa Active Knowledge Sharing 
adalah salah satu strategi yang dapat membawa siswa untuk siap belajar materi pelajaran dengan cepat. Strategi ini dapat digunakan untuk melihat tingkat kemampuan siswa dengan membentuk kerjasama tim serta menuntut siswa menjadi lebih aktif dalam proses pembelajaran.

Pada akhir pembelajaran akan diadakan kuis. Haryati (2007 : 80) mengatakan bahwa: "kuis adalah pernyataan yang diajukan kepada peserta didik, dimana pernyataan itu hanya menanyakan hal-hal yang prinsip saja dari materi yang telah diajarkan sebelumnya dan bentuknya berupa isian singkat". Kuis diberikan untuk melihat perkembangan pemahaman konsep matematis siswa setiap kali pertemuan.

Berdasarkan uraian diatas, dilakukan penelitian yang berjudul "Pengaruh Penerapan Strategi Pembelajaran Aktif Tipe Active Knowledge Sharing Disertai Kuis terhadap Pemahaman Konsep Matematis Siswa Kelas X SMA Dr. H. Abdullah Ahmad PGAI Padang ”

Penelitian ini bertujuan untuk untuk mengetahui: 1) bagaimana perkembangan pemahaman konsep matematis siswa selama menerapkan strategi pembelajaran aktif tipe Active Knowledge Sharing. 2) apakah pemahaman konsep matematis siswa selama menerapkan model pembelajaran aktif tipe Active Knowledge Sharing disertai kuis lebih baik daripada pemahaman konsep matematis siswa dengan menerapkan pembelajaran konvensional di kelasX SMA Dr. H. Abdullah Ahmad PGAI Padang.

Penelitian relevan dengan penelitian ini adalah penelitian yang dilakukan oleh Kurnia Sari pada tahun 2013 yang berjudul "Pengaruh Penerapan Strategi Pembelajaran Aktif Tipe Active Knowledge Sharing terhadap pemahaman konsep matematis siswa kelas VIII SMPN 4 Kota Solok. Kesimpulan yang diperoleh adalahpemahaman konsep matematis siswa dengan penerapan strategi pembelajaran aktif tipe Active Knowledge Sharing lebih baik daripada pemahaman konsep matematis siswa dengan menggunakan model pembelajaran konvensional.

\section{METODE PENELITIAN}

Jenis penelitian ini adalah penelitian eksperiment. Penelitian dilaksanakan pada tanggal 10 Januari s/d 04 Februari 2017 di kelas X SMA Dr. H. Abdullah Ahmad PGAI Padang. Terpilih kelas X.2 sebagai kelas eksperimen dan kelas X.1 sebagai kelas kontrol. 
Instrumen penelitian berupa kuis dan tes akhir. Soal tes akhir diujicobakan terlebih dahulu.Uji coba soal dilakukan di SMA PGRI 1Padang untuk mengetahui apakah instrumen yang digunakan dapat dipercaya sebagai alat pengumpulan data.Menurut Arikunto (2010: 228) kriteria koefisien reliabilitas tes $\left(r_{11}\right)$ dibandingkan dengan nilai rproduct moment $\left(r_{\text {tabel }}\right)$. Jika $r_{11}$ lebih kecil dari harga $r_{\text {tabel }}$, maka instrument penelitian reliabel. Berdasarkan hasil perhitungan diperoleh $r_{11}=$ 0,95 dan $r_{\text {tabel }}=0,456$ dengan demikian $r_{11}>r_{\text {tabel }}$. Jadi dapat disimpulkan bahwa soal tes reliabel.

\section{HASIL DAN PEMBAHASAN}

Berdasarkan penelitian yang yang telah dilakukan pada kedua kelas sampel diperoleh data mengenai pemahaman konsep matematis siswa sebagai berikut:

a. Perkembangan Pemahaman Konsep Matematis Siswa

Perkembangan pemahaman konsep matematis siswa dilihat melalui kuis. Nilai rata-rata kuis selama lima pertemuan pada kelas eksperimen dapat dilihat padaTabel1.

Tabel 1. Rata-rata Nilai Kuis Siswa

\begin{tabular}{|c|c|c|c|c|c|}
\hline Kuis & I & II & III & IV & V \\
\hline $\bar{x}$ & 70,82 & 60,8 & 88,1 & 71.5 & 73,91 \\
\hline
\end{tabular}

Tabel 1 menunjukkan bahwa rata-rata nilai kuis pada setiap pertemuan mengalami penurunan dan peningkatan. Rata-rata kuis I ke kuis II mengalami penurunan. Hal ini disebabkan karena pada pertemuan kedua sebagian siswa kurang mampu pada indikator menyatakan ulang sebuah konsep, siswa belum mampu menentukan nilai kebenaran pernyataan majemuk berbentuk implikasi dan biimplikasi dengan tiga pernyataan. Kuis II ke kuis III mengalami peningkatan,siswa sudah mampu menentukan ingkaran/ negasi dari suatu pernyataan majemuk. Kuis III ke kuis IV mengalami penurunan kembali. Hal ini disebabkan karena sebagian siswa belum mampu mengklasifikasikan objek menurut sifat-sifat tertentu sesuai dengan konsepnya sebagian siswa sering terbalik dalam menentukan invers dan kontraposisi pada implikasi pernyataan majemuk dan guru tidak sempat memberikan penguatan/ kesimpulan diakhir pembelajaran karena waktu banyak terpakai pada saat presentasi.

b. Tes Akhir 
Berdasarkan penelitian yang telah dilakukan pada kedua kelas sampel diperoleh nilai rata-rata $(\bar{x})$, simpangan baku $(\mathrm{S})$, skor tertinggi $\left(x_{\max }\right)$, skor terendah $\left(x_{\min }\right)$ dari tes akhir kelas sampel sesuai dengan Tabel 2.

Tabel 2. Hasil Perhitungan Nilai Tes Akhir Siswa Kelas Sampel

\begin{tabular}{|c|c|c|c|c|}
\hline KelasSampel & $\overline{\boldsymbol{X}}$ & $\mathbf{S}$ & $\boldsymbol{X}_{\text {maks }}$ & $\boldsymbol{X}_{\min }$ \\
\hline Eksperimen & 72,94 & 17,03 & 97,33 & 40 \\
\hline Kontrol & 58,48 & 27,81 & 93,33 & 16 \\
\hline
\end{tabular}

Berdasarkan tabel 2 dapat dilihat bahwa nilai rata-rata siswa kelas eksperimen lebih tinggi daripada nilai rata-rata siswa kelas kontrol. Sedangkan simpangan baku kelas eksperimen lebih kecil dibandingkan dengan simpangan baku kelas kontrol. Hal ini menunjukkan bahwa pada kelas eksperimen memiliki keragaman yang kecil, sehingga menyebabkan pada umumnya nilai siswa tersebar tidak terlalu jauh dari nilai rata-rata kelas. Selain itu, jika dilihat dari nilai maksimum dan minimum yang diperoleh siswa pada kelas eksperimen lebih tinggi dibandingkan kelas kontrol.

Hasil perhitungan pada uji hipotesis diperoleh $t_{\text {hitung }}=1,746$ dan $t_{\text {tabel }}=1,697$ pada $\alpha=0.05$ maka $t_{\text {hitung }}>t_{\text {tabel }}$, dengan demikian $H_{0}$ diterima. Sehingga dapat disimpulkan bahwa pemahaman konsep matematis siswa dengan menerapkan strategi pembelajaran aktif tipe Active Knowledge Sharing disertai kuis lebih baik daripa da pemahaman konsep matematis siswa dengan menerapkan pembelajaran konvensional di kelas X SMA Dr. H. Abdullah Ahmad PGAI Padang Tahun Pelajaran 2016/2017.

Pelaksanaan proses pembelajaran aktif tipe Active Knowledge Sharing pada pertemuan pertama belum berjalan dengan baik. Siswa masih terlihat bingung dengan penjelasan dan instruksi yang diberikan guru mengenai langkah-langkah strategi pembelajaran aktif tipe Active Knowledge Sharing. Contoh jawaban siswa dalam menjawab lembar pertanyaan dari guru dapat dilihat pada gambar 1. 
3. Tulislah disjungsi dari masing-masing pernyataan berikut, kemudian tentukan nilai kebenarannya.

a. $p: 4+5=9$

$q: 9$ habis dibagi 2

b. $p: 17$ bilangan ganjil

$q: 17$ bilangan prima

c. $p$ :Matahari terbit di barat

$q$ : Matahari tenggelam di timur

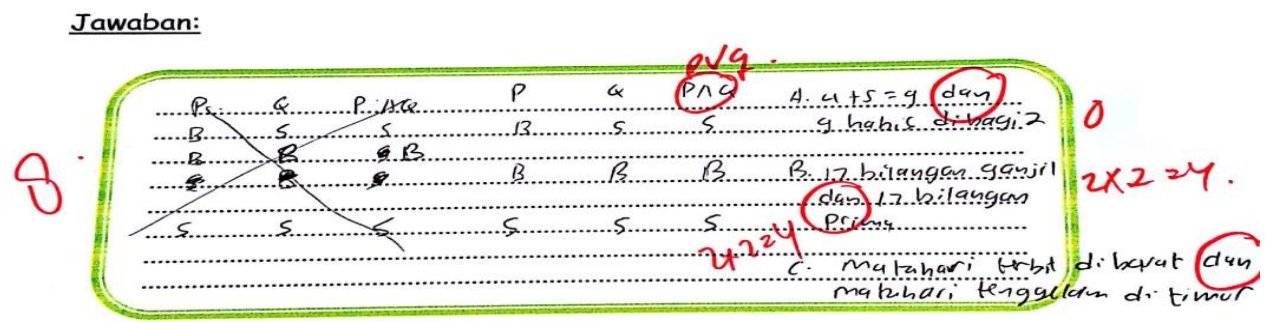

Gambar 1. Contoh hasil kerja siswa pada pertemuan I

Gambar 1 menunjukkan siswa telah mampu menentukan nilai kebenaran dari masing-masing pernyataan dengan sedikit kesalahan. Siswa masih ragu menentukan simbol dari konjungsi dan disjungsi dan siswa masih ragu dalam menentukan nilai kebenaran dari suatu pernyataan majemuk berbentuk disjungsi.

Guru menunjuk siswa secara acak untuk mempresentasikan hasil diskusi kedepan kelas. Diakhir pembelajran guru mengadakan kuis untuk melihat bagaimana gambaran perkembangan pemahaman konsep matematis siswa.Berikut contoh jawaban kuis siswa pada pertemuan pertama dapat dilihat pada gambar 2 .

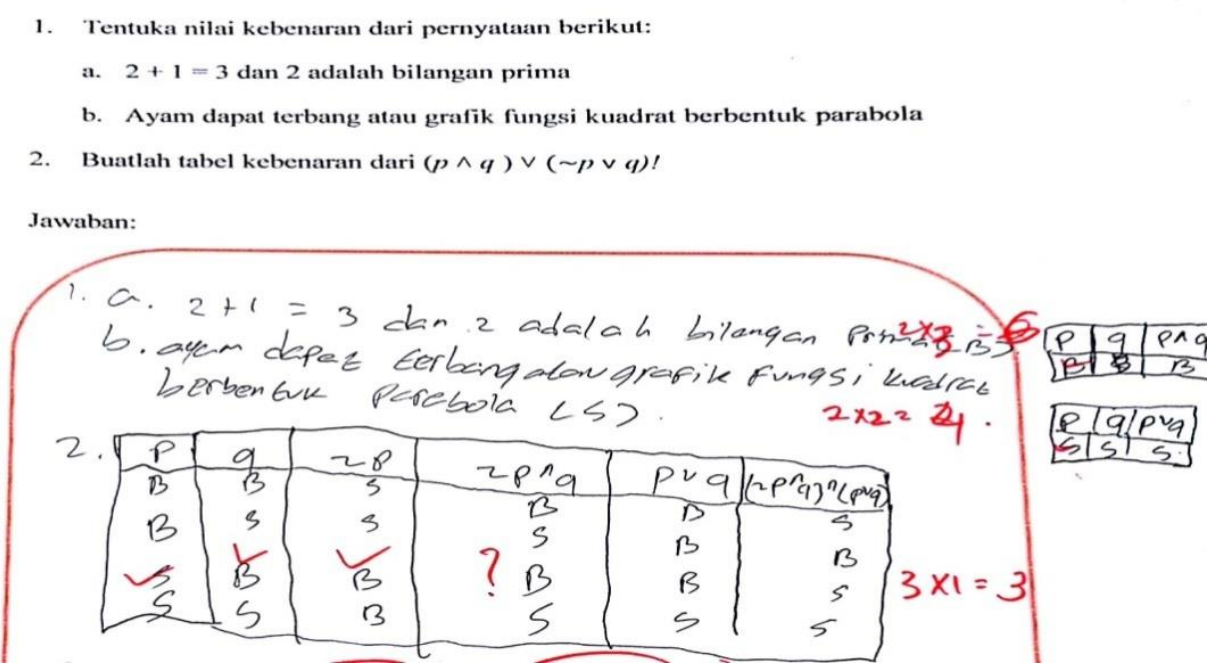

Gambar 2.Jawaban kuis pertemuan I

Gambar 2 menunjukkan siswa telah mampu menentukan nilai kebenaran dari masing-masing pernyataan. Namun siswa masih ragu menentukan tabel kebenaran dari 
konjungsi dan disjungsi. Hal ini dapat dilihat dari hasil jawaban siswa soal nomor 2 pada gambar 2 .

Proses pembelajaran di kelas kontrol dilaksanakan sesuai denganpembelajaranyang biasa terlaksana disekolah tersebut, yang diistilahkan dengan pembelajaran konvensional yaitu diawali dengan guru menjelaskan materi dan memberikan contoh soal setelah itu guru memberikan soal latihan untuk dikerjakan oleh siswa secara individu.

Setelah pokok pembelajaran selesai dipelajari, kedua kelas sampel diberikan tes akhir. Hasil tes akhir siswa kelas eksperimen dapat dilihat pada gambar 3.

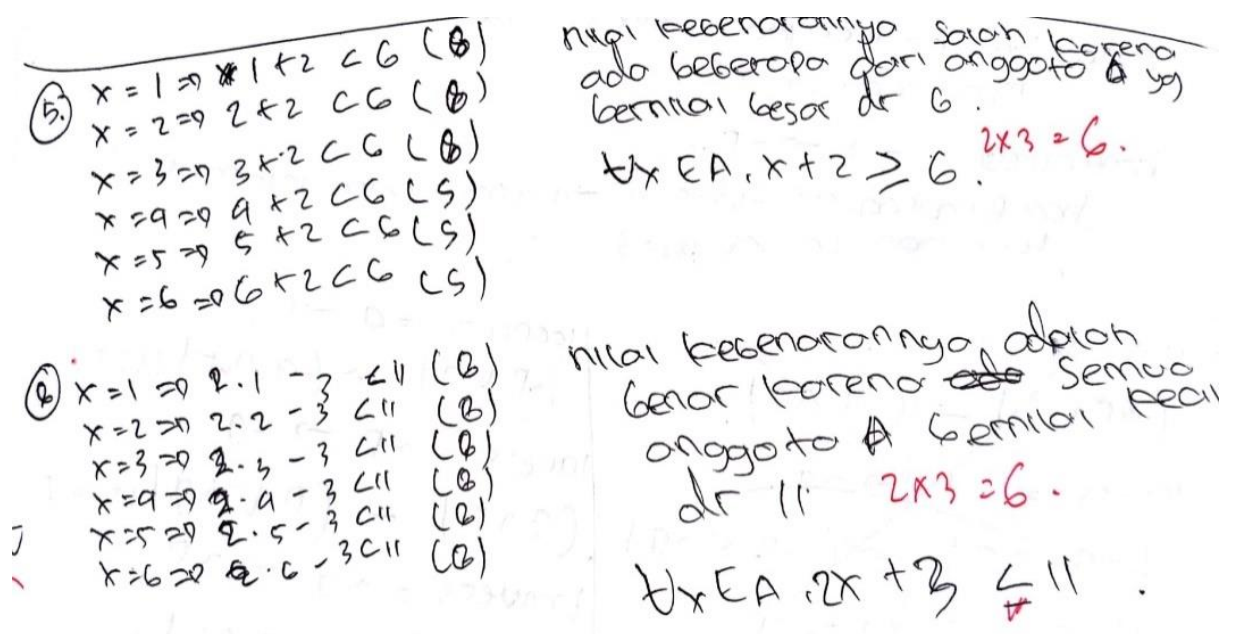

Gambar 3. Hasil tes akhir siswa kelas eksperimen

Berdasarkan Gambar 3 dapat terlihat bahwa siswa telah mampu menyajikan konsep dalam berbagai bentuk representasi matematis dengan membuat nilai kebenaran untuk semua anggota bilangan A. Siswa juga telah mampu menyatakan ulang sebuah konsep ingkaran dari pernyataan berkuantor dengan menuliskan jawaban dengan benar.

Hasil tes akhir siswa kelas konroldapat dilihat pada gambar 4.

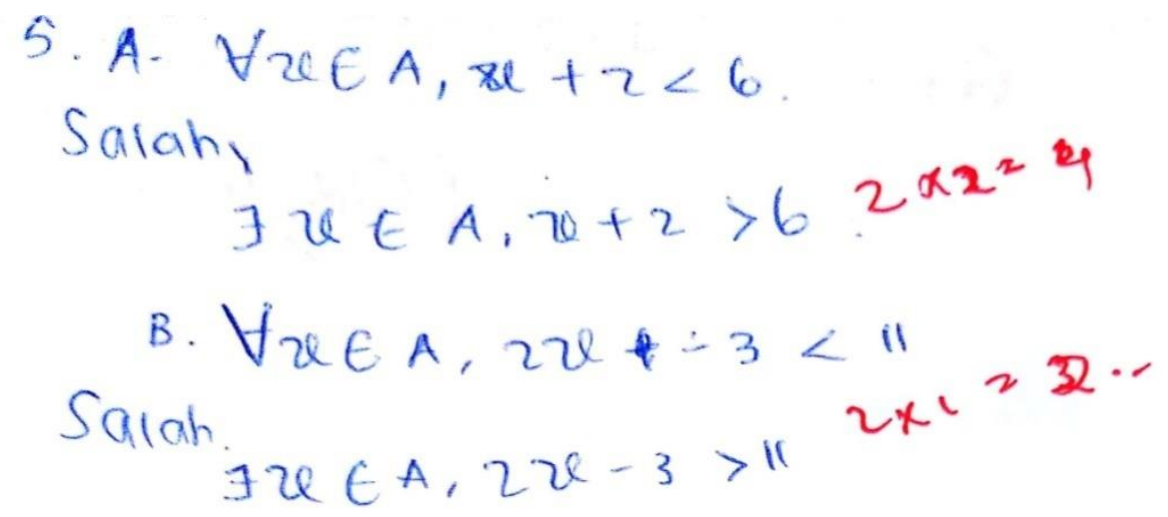

Gambar 4. Hasil tes akhir siswa kelas kontrol 
Berdasarkan Gambar 4 terlihat bahwa siswa kelas kontrol belum mampu menyajikan konsep dalam berbagai bentuk representasi matematis, hal in dapatdilihatdarijawabansiswa belum mampu menentukan nilai kebenaran untuk semua anggota bilangan A pada soal. Namunsiswa sudah mampu menyatakan ulang konsep ingkaran dari penyataan berkuantor dengan benar.

Pemahaman konsep matematis siswa lebih bagus di kelas eksperimen dibandingkan kelas kontrol. Hal ini karena selama penerapan strategi pembelajaran aktif tipe Active Knowledge Sharing disertai kuis di kelas eksperimen siswa dituntut untuk teribat aktif dalam memahami materi yang dipelajari dan berbagi pengetahuan secara aktif dengan temannya. Sedangkan pada kelas kontrol siswa kurang terlibat aktif selama proses pembelajaran, karena pembelajaran terpusat pada guru sehingga siswa terbiasa menunggu penjelasan dari guru.

\section{KESIMPULAN}

Berdasarkanhasilpenelitiandanpembahasandapatdisimpulkanbahwa:

1. Perkembangan pemahaman konsep matematis siswa dengan penerapan strategi pembelajaran aktif tipe Active Knowledge Sharing disertai kuis mengalami penurunan dan peningkatan.

2. Pemahaman konsep matematis siswa dengan menerapkan strategi pembelajaran aktif tipe Active Knowledge Sharing disertai kuis lebih baik daripada pemahaman konsep matematis siswa dengan penerapan pembelajaran konvensionalpada siswa kelasX SMA Dr. H. Abdullah Ahmad PGAI Padang tahun pelajaran 2016/2017.

\section{UCAPAN TERIMA KASIH}

Terima kasih kepada Bapak/ Ibu yang telah membantu dalam penyelesaian penelitian ini.

1. Kepala Sekolah SMA Dr. H. Abdullah Ahmad PGAI Padang

2. Kepala Sekolah SMA PGRI 1 Padang

3. Ketua STKIP PGRI Sumatera Barat

4. Pembimbing

\section{DAFTAR PUSTAKA}

Arikunto, Suharsimi. (2010). Prosedur Penelitian Suatu Pendekatan Praktik .Jakarta :RinekaCipta 
Haryati, Mimin (2007).Model dan Teknik Penilaian Pada Tingkat Satuan Pendidikan .Jakarta: GaungPersada Press

Muliyardi.(2002). StrategiPembelajaranMatematika. Padang: FMIPA UNP

Sari,Kurnia. (2013). Pengaruh Penerapan Strategi Pembelajaran Aktif Tipe Active Knowledge Sharing Terhadap Pemahaman Konsep Matematis Siswa Kelas VIII SMPN 4 Kota Solok. Skripsi tidak diterbitkan. Padang: STKIP PGRI Sumbar.

Zaini, Hisyam. (2008). Strategi Pembelajaran Aktif. Yogyakarta: PustakaInsanMadani 